\title{
PENGARUH BRAND IMAGE DAN KUALITAS PRODUK TERHADAP KEPUTUSAN PEMBELIAN PADA KFC DI KOTA BENGKULU
}

\author{
Yudi Irawan Abi \\ Manajemen, Fakultas Ekonomi, Universitas Dehasen, Indonesia
}

\begin{abstract}
Abstrak
Tujuan penelitian ini adalah melihat pengaruh brand image dan kualitas produk terhadap keputusan pembelian Produk KFC di Kota Bengkulu. Penelitian ini dilakukan berdasarkan pendekatan kuantitatif. Data dikumpulkan menggunakan kuisioner dengan melibatkan 100 responden. Analisis data digunakan menggunakan regresi linear berganda. Hasil penelitian ini mengungkapkan bahwa pengaruh brand image berpengaruh signifikan terhadap keputusan pembelian pada Produk KFC di Kota Bengkulu. Pengaruh kualitas produk berpengaruh signifikan terhadap keputusan pada Produk KFC di Kota Bengkulu.
\end{abstract}

Kata Kunci: Kualitas produk; Brand image; dan Keputusan Pembelian.

\begin{abstract}
The purpose of this study is to look at the effect of brand image and product quality on purchasing decisions for KFC products in the city of Bengkulu. This research was conducted based on a quantitative approach. Data were collected using a questionnaire involving 100 respondents. Data analysis was used using multiple linear regression. The results of this study reveal that the influence of brand image has a significant effect on purchasing decisions on KFC products in Bengkulu City. The effect of product quality has a significant effect on decisions on KFC products in Bengkulu City.

Keywords: product quality; Product Knowledge; and Purchase Decision.
\end{abstract}

Article History: Received: (30-01-2020); Revised: (28-02-2020); and Published: (30-04-2020) Copyright $@ 2020$ Yudi Irawan Abi

How to cite this article: Abi, Y.I. (2020). Pengaruh Brand Image Dan Kualitas Produk Terhadap Keputusan Pembelian Pada Kfc Di Kota Bengkulu. Managament Insight: Jurnal Ilmiah Manajemen. 15(1), 95-107 


\section{PENDAHULUAN}

Persaingan bisnis pada era globalisasi menjadi semakin tajam baik di pasar domestik (nasional) maupun internasional. Perkembangan dunia usaha yang dinamis dan penuh persaingan menuntut perusahaan untuk melakukan perubahan orientasi terhadap cara mereka mengeluarkan produk, mempertahankan produknya, menarik konsumen, dan menangani pesaing (Tjiptono, 2005). Salah satu hal penting yang perlu dilakukan dan diperhatikan oleh setiap perusahaan adalah menarik pelanggan dan dapat mempertahankan pelanggan tersebut. Pelaku bisnis memikirkan bagaimana caranya agar usaha dalam bisnis dapat memperoleh keuntungan yang meningkat dengan cara menambah pelanggan yang baru dan mempertahankan pelanggan yang lama. Pelanggan adalah suatu aset perusahaan untuk mendapatkan keuntungan dari hasil penjualan kepada Pelanggan. Pelaku bisnis berusaha menciptakan keputusan pembelian agar pelanggan tetap setia dengan produk yang telah digunakan selama ini. Salah satu cara agar pelanggan tetap setia menggunakan produk, maka pelaku usaha harus senantiasa berinovasi untuk memberikan manfaat lebih selain menawarkan produk inti dari produk atau jasa yang ditawarkan.

Persaingan yang ketat secara tidak langsung akan mempengaruhi suatu perusahaan dalam mempertahankan pangsa pasar, perusahaan harus bekerja keras dalam mempertahankan membeli konsumennya. Karena hal itulah, upaya menjaga keputusan pembelian merupakan hal penting yang harus selalu dilakukan oleh perusahaan. Mempertahankan semua pelanggan yang ada pada umumnya akan lebih menguntungkan dibandingkan dengan pergantian pelanggan karena biaya untuk menarik pelanggan baru bisa lima kali lipat dari biaya mempertahankan seorang pelanggan yang sudah ada (Kotler \& Kevin, 2009).

Perusahaan harus mampu mengenal apa yang menjadi kebutuhan dan harapan konsumen saat ini maupun yang akan datang. Konsumen sebagai individu dalam mendapatkan atau membeli barang telah melalui proses-proses atau tahapan-tahapan terlebih dahulu, seperti mendapat informasi baik melalui iklan atau referensi dari orang lain (word of mouth) kemudian membandingkan produk satu dengan produk yang lain sampai akhirnya mengkonsumsinya dan berdasarkan pengalaman tersebut konsumen akan membeli produk yang sama. Salah satu jalan untuk meraih keunggulan kompetisi dalam mempertahankan keputusan pembelian adalah dengan membentuk brand image (citra merek) yang baik di mata konsumen. Brand (merek) dewasa ini berkembang menjadi sumber aset terbesar bagi perusahaan. Suatu perusahaan beroperasi untuk mendapatkan profit atau keuntungan, juga untuk mempertahankan kelangsungan hidup bisnisnya. Suatu perusahaan untuk memenangkan persaingan dituntut melakukan strategi pemasaran bagi produk-produk yang dihasilkan. Dalam kondisi semakin meningkatnya persaingan produk-produk sejenis dan perilaku konsumen yang cenderung ingin mencoba merek-merek baru yang dikeluarkan oleh perusahaan pesaing untuk mendapatkan kepuasan, manfaat yang lebih, dan memenuhi rasa ingin tahu terhadap merek baru tersebut.

Konsumen dalam memilih suatu merek produk akan melalui tahap percobaan terlebih dahulu, pada tahap ini seringkali konsumen akan mencoba berbagai merek 
yang berbeda. Jika dirasakan merek tersebut cocok dan memenuhi apa yang diharapkan dari produk sejenis, maka konsumen akan terus mencari merek tersebut. Brand atau merek adalah nama, istilah, tanda, simbol desain, ataupun kombinasinya yang mengidentifikasi suatu produk atau jasa yang dihasilkan oleh suatu perusahaan. (Durianto, 2011)

Kualitas produk menjadi perhatian penting bagi perusahaan dalam menciptakan sebuah produk. Produk yang berkualitas menjadi kriteria utama konsumen dalam pemilihan produk yang ditawarkan oleh perusahaan. Perusahaan senantiasa mampu mempertahankan dan meningkatkan kualitas produk guna memenuhi keinginan konsumen. Dengan produk yang berkualitas perusahaan dapat bersaing dengan para kompetitor dalam menguasai pangsa pasar. Dengan memberikan perhatian pada kualitas akan memberikan dampak yang positif kepada bisnis melalui dua cara yaitu dampak terhadap biaya produksi dan dampak terhadap pendapatan (Gaspersz, 2005). Dampak terhadap biaya produksi terjadi melalui proses pembuatan produk yang memiliki derajat konformasi yang tinggi terhadap standar-standar sehingga bebas dari tingkat kerusakan. Dampak terhadap peningkatan pendapatan terjadi melalui peningkatan penjualan atas produk berkualitas yang berharga kompetitif. Dengan memperhatikan aspek kualitas produk, maka tujuan perusahaan untuk memperoleh laba yang optimal dapat terpenuhi sekaligus dapat memenuhituntutan konsumen akan produk yang berkualitas dan harga yang kompetitif.

Salah satu produk makanan yang cukup besar di indonesia adalah KFC. Produk KFC yang di keluarkan oleh perusaahan internasional memberikan jaminan kualitas produk yang baik. Persepsi KFC sebagai produk yang berkualitas, aman dan halal telah cukup kuat menempel di mata masyarakat Indonesia. Jika di tanya tempat makan ayam goreng terbaik di indonesia, KFC-lah yang terlintas di benak mereka. Artinya Brand Image yang terbentuk mengenai produk sudah kuat.

Semakin kuat Brand image di benak pelanggan maka semakin kuat pula rasa percaya diri pelanggan untuk menentukan keputusan pembelian terhadap produk yang dibelinya sehingga hal tersebut dapat mengantar sebuah perusahaan untuk tetap berkembang mendapatkan keuntungan dari waktu ke waktu. Persaingan semakin meningkat diantara merek-merek yang beroperasi dipasar. Hanya produk yang memiliki brand image yang kuat yang tetap mampu bersaing dan mampu menguasai pasar (Janita dkk, 2014).

Thakur (2012), Merek merupakan simbol atau tanda yang membantu bagi pelanggan untuk mengidentifikasi produk. Perusahaan yang memiliki produk dengan Brand Image yang menguntungkan, oleh masyarakat pasti yang diperoleh posisi yang lebih baik di pasar juga dapat mempertahankan keunggulan kompetitif dan meningkatkan jumlah pangsa pasar (Tjiptono, 2005). Semakin tinggi kualitas produk yang dihasilkan oleh sebuah perusahaan, maka akan semakin menentukan keputusan pelanggan untuk membeli dan mengkonsumsi produk tersebut.

Konsumen dalam memilih suatu merek produk akan melalui tahap percobaan terlebih dahulu, pada tahap ini seringkali konsumen akan mencoba berbagai merek yang berbeda. Jika dirasakan merek tersebut cocok dan memenuhi apa yang diharapkan dari produk sejenis, maka konsumen akan terus mencari merek tersebut. 
Brand atau merek adalah nama, istilah, tanda, simbol desain, ataupun kombinasinya yang mengidentifikasi suatu produk atau jasa yang dihasilkan oleh suatu perusahaan. (Durianto, 2011)

Salah satu produk makanan dengan brand image yang cukup besar adalah KFC. Produk KFC yang di keluarkan oleh perusaahan internasional memberikan jaminan kualitas produk yang baik. Persepsi KFC sebagai produk yang berkualitas, aman dan halal telah cukup kuat menempel di mata masyarakat Indonesia. Jika di tanya tempat makan ayam goreng terbaik di indonesia, KFC-lah yang terlintas di benak mereka. Artinya Brand Image yang terbentuk mengenai produk sudah kuat.

Semakin kuat Brand image di benak pelanggan maka semakin kuat pula rasa percaya diri pelanggan untuk menentukan keputusan pembelian terhadap produk yang dibelinya sehingga hal tersebut dapat mengantar sebuah perusahaan untuk tetap berkembang mendapatkan keuntungan dari waktu ke waktu. Persaingan semakin meningkat diantara merek-merek yang beroperasi dipasar. Hanya produk yang memiliki brand image yang kuat yang tetap mampu bersaing dan mampu menguasai pasar (Janita dkk, 2014).

Thakur (2012), Merek merupakan simbol atau tanda yang membantu bagi pelanggan untuk mengidentifikasi produk. Perusahaan yang memiliki produk dengan Brand Image yang menguntungkan, oleh masyarakat pasti yang diperoleh posisi yang lebih baik di pasar juga dapat mempertahankan keunggulan kompetitif dan meningkatkan jumlah pangsa pasar (Tjiptono, 2005). Semakin baik kualitas produk dan Brand Image yang dihasilkan oleh sebuah perusahaan, maka akan semakin menentukan keputusan pelanggan untuk membeli dan mengkonsumsi produk tersebut.

\section{TINJAUAN PUSTAKA}

\section{Brand Image}

Brand image (Citra Merek) merupakan representasi dari keseluruhan persepsi terhadap merek dan dibentuk dari informasi dan pengalaman masa lalu terhadap merek itu. Citra terhadap merek berhubungan dengan sikap yang berupa keyakinan dan preferensi terhadap suatu merek. Konsumen yang memiliki citra yang positif terhadap suatu merek, akan lebih memungkinkan untuk melakukan pembelian (Setiadi, 2003). Merek dapat dideskripsikan dengan karakteristik-karakteristik tertentu seperti manusia, semakin positif deskripsi tersebut semakin kuat Brand image dan semakin banyak kesempatan bagi pertumbuhan merek itu. (David, 2006). Brand image adalah sekumpulan asosiasi merek yang terbentuk pada benak konsumen (Mowen, 2002).

Brand image mengacu pada skema memori akan sebuah merek, yang berisikan interpretasi konsumen atas atribut, kelebihan, penggunaan, situasi, para penggunadan karakteristik pemasar dan/atau karakteristik pembuat dari produk/merek tersebut. Brand image adalah apa yang konsumen pikirkan dan rasakan ketika mendengar atau melihat nama suatu merek (Hawkins, et.al. 1998). Brand image meliputi pengetahuan dan kepercayaan akan atribut merek (aspek kognitif), konsekuensi dari penggunaan 
merek tersebutdan situasi penggunaan yang sesuai, begitu juga dengan evaluasi, perasaan dan emosi yang diasosiasikan dengan merek tersebut (aspek afektif). Brand image didefinisikan sebagai persepsi konsumen dan preferensi terhadap merek, sebagaimana yang direfleksikan oleh berbagai macam asosiasi merek yang ada dalam ingatan konsumen. Meskipun asosiasi merek dapat terjadi dalam berbagai macam bentuk tapi dapat dibedakan menjadi asosiasi performansi dan asosiasi imajeri yang berhubungan dengan atribut dan kelebihan merek. (Peter \& Olson, 2002).

Menurut Drezner (2002), konsumen tidak bereaksi terhadap realitas melainkan terhadap apa yang mereka anggap sebagai realitas, sehingga Brand image dilihat sebagai serangkaian asosiasi yang dilihat dan dimengerti oleh konsumen, dalam jangka waktu tertentu, sebagai akibat dari pengalaman dengan merek tertentu secara langsung ataupun tidak langsung. Asosiasi ini bisa dengan kualitas fungsional sebuah merek ataupun dengan individu dan acara yang berhubungan dengan merek tersebut. Meskipun tidak mungkin setiap konsumen memiliki citra yang sama persis akan suatu merek, namun persepsi mereka secara garis besar memiliki bagian-bagian yang serupa. Brand image adalah kesan keseluruhan terhadap posisi merek ditinjau dari persaingannya dengan merek lain yang diketahui konsumen, apakah merek tersebut dipandang konsumen sebagai merek yang kuat. Sebagian alasan konsumen memilih suatu merek karena mereka ingin memahami diri sendiri dan untuk mengkomunikasikan aspek diri ke orang lain (Arnould, et.al. 2005).

\section{Kualitas produk}

Produk merupakan objek yang berwujud, maupun yang tidak berwujud yang dapat dibeli orang (Harjanto, 2009). Pengertian kualitas produk menurut Kotler and Armstrong (2008) adalah sekumpulan ciri-ciri karakteristik dari barang dan jasa yang mempunyai kemampuan untuk memenuhi kebutuhan yang merupakan suatu pengertian dari gabungan daya tahan, keandalan, ketepatan, kemudahan pemeliharaan serta atribut-atribut lainnya dari suatu produk. Kotler dan Keller (2009) produk adalah segala sesuatu yang dapat di tawarkan ke pasar untuk memuaskan keinginan atau kebutuhan. Kualitas produk adalah kecocokan penggunaan produk (fitness for use) untuk memenuhi kebutuhan dan kepuasan konsumen, Juran dalam (Nasution, 2005).

Nasution (2005) kualitas produk adalah suatu kondisi dinamis yang berhubungan dengan produk, manusia/tenaga kerja, proses dan tugas, serta lingkungan yang memenuhi atau melebihi harapan Konsumen atau konsumen. Tjiptono (2012) mendefinisikan kualitas sebagai tingkat mutu yang diharapkan dan pengendalian keragaman dalam mencapai mutu tersebut untuk memenuhi kebutuhan konsumen, sedangkan menurut Kotler dan Amstrong (2008), kualitas produk adalah kemampuan suatu produk untuk melaksanakan fungsinya, meliputi daya tahan, kehandalan, kemudahan operasi dan perbaikan, serta atribut nilai.. 
Kotler (2009), menyatakan bahwa kualitas produk merupakan kemampuan sebuah produk dalam memperagakan fungsinya, hal itu termasuk keseluruhan durabilitas, reliabilitas, ketepatan, kemudahan pengoperasian dan reparasi produk juga atribut produk lainnya. Orang akan memuaskan keinginan dan kebutuhannya melalui produk. Istilah lain yang dipakai untuk menyebutkan produk adalah penawaran dan pemecahan. Produk atau penawaran dapat dibedakan menjadi tiga jenis yaitu barang fisik, jasa dan gagasan. Tingkat kepentingan produk fisik lebih tergantung pada jasa yang mereka berikan pada pemiliknya, sehingga produk fisik sebenarnya adalah sarana yang memberikan jasa pada kita. Produk adalah segala sesuatu yang dapat ditawarkan kepada pasar untuk memuaskan suatu keinginan atau kebutuhan, termasuk barang fisik, jasa, pengalaman, acara, orang, tempat, properti, organisasi, informasi, dan ide (Kotler dan Amstrong, 2008).

\section{Keputusan Pembelian}

Keputusan pembelian merupakan serangkaian proses yang berawal dari konsumen mengenal masalahnya, mencari informasi tentang produk atau merek tertentu dan mengevaluasi produk atau merek tersebut seberapa baik masing-masing alternatif tersebut dapat memecahkan masalahnya, yang kemudian serangkaian proses tersebut mengarah kepada keputusan pembelian (Tjiptono, 2014).

Kehidupan manusia tidak lepas dari melakukan jual beli. Sebelum melakukan pembelian, seseorang biasanya akan melakukan keputusan pembelian terlebih dahulu terhadap suatu produk. Keputusan pembelian merupakan kegiatan individu yang secara langsung terlibat dalam pengambilan keputusan untuk melakukan pembelian terhadap produk yang ditawarkan oleh penjual. Keputusan pembelian, menurut Kotler \& Amstrong (2008) adalah tahap dalam proses pengambilan keputusan pembeli di mana konsumen benar-benar membeli. Pengambilan keputusan merupakan suatu kegiatan individu yang secara langsung terlibat dalam mendapatkan dan mempergunakan barang yang ditawarkan. Definisi lain keputusan pembelian adalah keputusan pembeli tentang merek mana yang dibeli. Konsumen dapat membentuk niat untuk membeli merek yang paling disukai. Keputusan pembelian merupakan suatu proses pengambilan keputusan akan pembelian yang mencakup penentuan apa yang akan dibeli atau tidak melakukan pembelian (Kotler dan Amstrong, 2008). Menurut Kotler (2005), "Keputusan pembelian adalah Suatu tahap dimana konsumen telah memiliki pilihan dan siap untuk melakukan pembelian atau pertukaran antara uang dan janji untuk membayar dengan.

Selanjutnya Kotler dan Keller (2009) menambahkan bahwa, proses keputusan pembelian adalah proses lima tahap yang dilewati konsumen, dimulai dari pengenalan masalah, pencarian informasi, evaluasi alternative yang dapat memecahkan masalahnya, keputusan pembelian, dan perilaku pasca pembelian, yang dimulai jauh sebelum pembelian yang sesungguhnya dilakukan oleh konsumen dan memiliki dampak yang lama setelah itu. 


\section{Pengaruh Brand Image terhadap Keputusan Pembelian}

Pengaruh antara Brand Image dengan keputusan pembelian terletak pada keinginankeinginan dan pilihan konsumen (preference) atas suatu merek adalah merupakan sikap konsumen. Dalam banyak hal, sikap terhadap merek tertentu sering mempengaruhi apakah konsumen akan beli atau tidak. Persepsi yang baik dan kepercayaan konsumen akan suatu merek tertentu akan menciptakan minat beli konsumen dan bahkan meningkatkan keputusan pembelian terhadap produk tertentu. Teori penghubung antara Brand Image dengan keputusan pembelian dikutip dari Rangkuti (2002) yang mengatakan: "Apabila konsumen beranggapan bahwa merek tertentu secara fisik berbeda dari merek pesaing, Brand Image tersebut akan melekat secara terus menerus sehingga dapat membentuk kesetiaan terhadap merek tertentu yang disebut dengan membeli merek. Konsumen yang ingin membeli produk KFC akan berusaha mencari informasi mengenai jamu tersebut karena ini akan mempengaruhi keputusan pembelian mereka. Semakin banyak informasi yang konsumen dapatkan, semakin banyak pertimbangan untuk memutuskan pembelian Produk KFC tersebut. Oleh sebab itu, hipotesis pertama sebagai berikut:

$\mathrm{H} 1$ : Brand image berpengaruh secara positif terhadap keputusan pembelian

\section{Pengaruh Kualitas produk terhadap Keputusan Pembelian}

nugroho (2011) menyatakan salah satu strategi yang efektif dalam mengatasi hal ini adalah kualitas produk, kualitas memiliki daya tarik bagi konsumen dan sangat mempengaruhi konsumen dalam memilih barang maupun jasa. Produk dikatakan berkualitas jika sesuai dengan kebutuhan dan keinginan pelanggan. Sangat penting pula mempertahankan kualitas, karena kualitas yang baik merupakan salah satu kunci keberhasilan perusahaan untuk mempertahakan pelanggannya, dimana produk yang baik akan menimbulkan keputusan membeli dan nantinya berdampak pada peningkatan keputusan pembelian pelanggan. Karena semakin tinggi kualitas produk yang diterima pelanggan maka semakin tinggi tingkat keputusan pembelian pelanggan tersebut.i. Oleh sebab itu, hipotesis kedua sebagai berikut:

H2: Kualitas produk berpengaruh secara positif terhadap keputusan pembelian

Model penelitian ini menguji beberapa variabel meliputi brand image, kualitas produk, dan keputusan pembelian. Berdasarkan pemaparan sebelumnya, secara ringkas penelitian ini menguji dua hipotesis (lihat Gambar 1). 


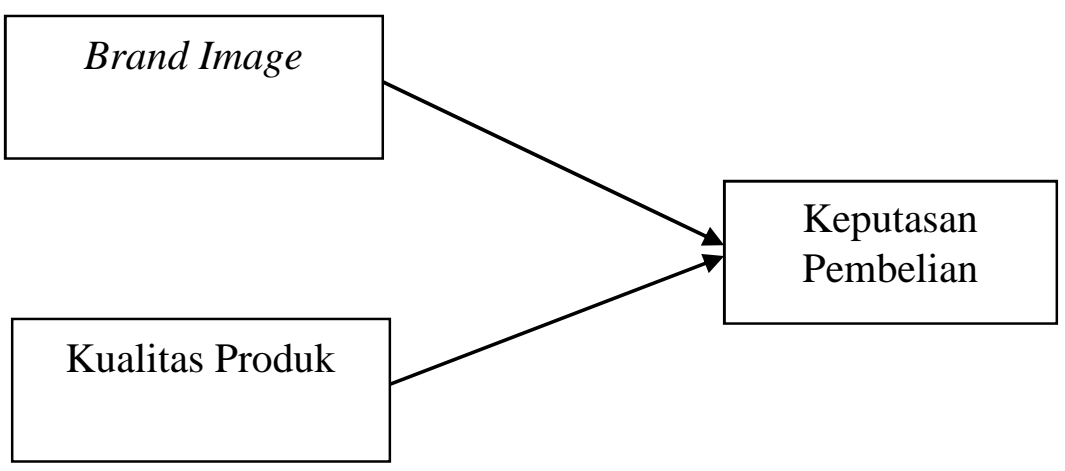

Gambar 1. Kerangka Penelitian

Sumber: Data diolah oleh peneliti (2020)

\section{METODE PENELITIAN}

Pada penelitian ini Jenis penelitian merupakan penelitian kuantitatif. Dimana penelitian kuantitatif atau statistic yang berupa perhitungan atau angka. Dengan melakukan penelitian kuantitatif dengan menganalisis angka-angka hasil angket, maka dapat dilihat seberapa besar pengaruh Brand image dan kualitas produk terhadap loyalitas pelanggan produk KFC di Kota Bengkulu. Ada beberapa item pertanyaan yang harus diisi oleh responden sebelum mengisi item pernyataan dari variabel penelitian. Responden dalam penelitian ini dipilih menggunakan teknik purposive sampling, untuk mendapatkan responden dengan kriteria yang telah ditentukan. Data selengkapnya mengenai profil responden dapat dilihat pada tabel-tabel berikut.

\section{Karakteristik Responden}

Jenis Kelamin

Hasil Tabel 1 menunjukkan bahwa sebanyak 36 persen responden berjenis kelamin laki-laki mengkonsumsi Produk KFC dan hanya 64 persen responden perempuan yang mengkonsumsi Produk KFC ini.

Tabel 1

Karakteristik Responden Berdasarkan Jenis Kelamin

\begin{tabular}{ccr}
\hline Jenis Kelamin & Frekuensi & Persentase \\
\hline Laki-laki & 36 & $36 \%$ \\
Perempuan & 64 & $64 \%$ \\
\hline \multicolumn{2}{c}{}
\end{tabular}

Usia

Hasil Tabel 2 menunjukkan bahwa responden dengan usia dari 19-24 tahun paling banyak mengkonsumsi Produk KFC, yaitu dengan persentase sebesar 36 persen. Selanjutnya, persentase usia responden terbesar kedua kurang dari 18 tahun dengan persentase sebesar 24 persen. Persentase usia responden terbesar ketiga, yaitu Abi

Pengaruh Brand Image dan Kualitas Produk Terhadap

Keputusan Pembelian pada KFC di Kota Bengkulu. 
responden yang berusia antara 25-29 tahun dengan persentase sebesar 22 persen. Responden yang berusia diatas 29 memiliki persentase terkecil sebesar 18 persen dalam mengkonsumsi Produk KFC.

Tabel 2

\section{Karakteristik Responden Berdasarkan Usia}

\begin{tabular}{ccc}
\hline Usia & Frekuensi & Persentase \\
\hline <18 Tahun & 24 & $24 \%$ \\
19-24 Tahun & 36 & $36 \%$ \\
25-29 Tahun & 22 & $22 \%$ \\
$>29$ Tahun & 18 & $18 \%$ \\
\hline
\end{tabular}

Sumber: Data Primer (2020)

\section{Pekerjaan}

Hasil Tabel 3 menujukkan bahwa pekerjaan responden paling banyak masih berstatus mahasiswa, yaitu sebesar 34 persen. Sebesar 24 persen responden bekerja sebagai Pelajar. Sebesar 23 persen responden bekerja sebagai Pegawai Negeri Sipil (PNS). Sebesar 19 persen responden bekerja swasta.

Tabel 3

Karakteristik Responden Berdasarkan Pekerjaan

\begin{tabular}{ccc}
\hline Pekerjaan & Frekuensi & Persentase \\
\hline Pelajar & 24 & $24 \%$ \\
Mahasiswa & 34 & $34 \%$ \\
Swasta & 19 & $19 \%$ \\
PNS & 23 & $23 \%$ \\
\hline
\end{tabular}

Sumber: Data Primer (2020)

\section{HASIL DAN PEMBAHASAN}

Pengujian hipotesis ini dilakukan setelah kriteria uji asumsi klasik terpenuhi. Hipotesis diterima apabila nilai dari $t_{\text {hitung }}$ lebih besari dari $t_{\text {tabel. }}$. Hasil pengujian hipotesis dari penelitian ini dapat dilihat pada Tabel 4 berikut ini.

\section{Tabel 4}

Hasil Pengujian Hipotesis

\begin{tabular}{ccccc}
\hline Variabel & $\begin{array}{c}\text { Koefisien } \\
\text { Regresi }\end{array}$ & Nilai t & Nilai P (Sig) & Keterangan \\
\hline brand image & 0,299 & 2,341 & 0,021 & $\begin{array}{c}\text { Hipotesis } \\
\text { diterima } \\
\text { kualitas produk }\end{array}$ \\
\hline 0,377 & 4,553 & 0,000 & $\begin{array}{c}\text { Hipotesis } \\
\text { diterima }\end{array}$ \\
\hline
\end{tabular}


Berdasarkan Tabel 4 diketahui bahwa hasil pengujian variabel brand image menunjukkan nilai $t$ hitung $=2,341$ dengan nilai signifikansi sebesar 0,021 0,05. Dengan nilai signifikansi di bawah 0,05 tersebut menunjukkan bahwa brand image memiliki pengaruh yang signifikan terhadap keputusan pembelian. Hal ini berarti bahwa variasi perubahan nilai variabel brand image dapat dijelaskan oleh variabel keputusan pembelian.

Berdasarkan Tabel 4 diketahui bahwa hasil pengujian variabel Feel menunjukkan nilai $\mathrm{t}$ hitung $=4,553$ dengan nilai signifikansi sebesar 0,00 0,05. Dengan nilai signifikansi di bawah 0,05 tersebut menunjukkan bahwa kualitas produk memiliki pengaruh yang signifikan terhadap keputusan pembelian. Hal ini berarti bahwa variasi perubahan nilai variabel kualitas produk dapat dijelaskan oleh variabel keputusan pembelian.

Pengujian hipotesis dengan menggunakan regresi menunjukkan bahwa kedua hipotesis terdukung. Pembahasan lebih komprehensif mengenai temuan penelitian lebih lanjut dibahas dan dijelaskan sebagai berikut.

\section{Pembahasan Hasil Pengujian Hipotesis Pertama}

Hasil uji hipotesis pertama ini menyatakan bahwa brand image berpengaruh positif dan signifikan terhadap keputusan pembelian. Hal ini brati brand image yang dimiliki produk KFC akan memengaruhi keputusan pembelian konsumen untuk membeli produk tersebut.

Penelitian ini juga di dukung oleh penelitaian Soim et al. (2016) yang menyatakan bahwa brand image berpengaruh positif dan signifikan terhadap keputusan pembelian. Dengan demikian, ketika dari brand image produk sudah, konsumen cenderung langsung ingin mnecoba produk tersebut. Konsumen sebelum memutuskan membeli produk KFC mereka mencari terlebih dahulu mengenai informasi tentang produk tersebut, jika citra produk tesebut sudan baik maka konsumen akan lamngsung membeli produk tersebut. Pengetahuan konsumen tentang suatu produk ini merupakan kekuatan yang kuat dalam mengarahkan perilaku konsumen yang akhirnya memutuskan untuk membeli atau tidak produk tersebut.

\section{Pembahasan Hasil Pengujian Hipotesis Kedua}

Hasil uji hipotesis kedua menyatakan bahwa kualitas produk berpengaruh positif dan signifikan terhadap keputusan pembelian. Hal ini brarti kualitas produk memiliki peran penting bagi konsumen untuk memutuskan pembelian terhadap Produk KFC.

Hasil ini didukung oleh penelitian yang dilakukan Supriyadi et al (2016) menunjukkan bahwa kualitas produk berpengaruh positif dan signifikan terhadap keputusan pembelian. ketika kualitas produk baik proses niat pembeli diperkirakan berlanjut menjadi pengambilan keputusan setelah konsumen melakukan pencarian informasi dan mengevaluasi kriteria suatu produk. Ketika evaluasi kriteria kualitas Produk KFC cocok dengan konsumen, konsumen akan segera memutuskan untuk Abi

Pengaruh Brand Image dan Kualitas Produk Terhadap

Keputusan Pembelian pada KFC di Kota Bengkulu. 
melakukan pembelian produk tersebut. Dengan demikian kualitas produk adalah hal yang sangat penting harus diperhatikan oleh produsen, karena perilaku pengambilan keputusan konsumen sangat yang terkait dengan kualitas produk yang ditawarkan oleh produsen.

\section{KESIMPULAN}

Brand image dan kualitas produk berpengaruh positif terhadap keputusan pembelian produk. Hasil penelitian ini menggambarkan bahwa sangat penting bagi konsumen dalam melihat Brand image dan kualitas produk yang ditawarkan oleh produsen sebagai bahan pertimbangan bagi konsumen untuk memilih produk KFC sebagi tempat makan yang para konsumen pilih.

Hasil penelitian ini bisa digunakan sebagai bahan pertimbangan bagi perusahaan Produk KFC untuk lebih memperhatikan informasi-informasi mengenai kualitaas produk yang dibutuhkan konsumen mengenai produk, baik itu pada iklan maupun kemasan. Ini dikarenakan brand image dan kualitas produk sangat memengaruhi keputusan pembelian Produk KFC oleh konsumen. Hal ini juga karena Produk KFC merupakan salah satu produk makanan yang sering di konsumsi oleh masyarakat.

\section{DAFTAR PUSTAKA}

Arnould, E., Price, L., Zinkan, G. 2005. Consumers 2nd ed. Singapore: McGrawHill/Irwin

David, Fred R. 2006. Strategic Management, Konsep. Ed. 10. Salemba Empat.

Drezner, W. 2002. A Balanced Perspective on Brands. Baringstroke : Mc Millan

Durianto, Darmadi, 2011, Strategi Menaklukkan Pasar Melalui Riset Ekuitas dan Perilaku Merek, Cetakan XX, Jakarta: PT. Gramedia Pustaka Utama

Gaspersz, Vincent. 2005. Sistem Manajemen Kinerja Terintegrasi Balanced Scorecard Dengan Six Sigma Untuk Organisasi Bisnis dan Pemeritah. Jakarta: Gramedia Pustaka Utama.

Hawkins, I. Best, R. J. Coney, K. 1998. Consumer Behavior: Building Market Strategy. USA: Irwin/ McGraw-Hill.

Harjanto, J.O. 2009, Inovasi Produk dan Ekspektasi Inovasi terhadapKeputusan Pembelian Konsumen. Erlangga. Jakarta. 
Janita, Inka S. dan Andriani Kusumawati. 2014. “Pengaruh Kualitas Produk dan Kualitas Pelayanan Terhadap Kepuasan Pelanggan Dalam Membembentuk Loyalitas Pelanggan (Studi pada Pelanggan McDonald's MT. Haryono Malang)", Jurnal administrasi Bisnis, Vol.15, No. 1. Oktober 2014.

Kotler, Philip dan Armstrong, Gary, 2008. Dasar-dasar Pemasaran.Alih bahasa Alexander Sindoro, Jilid I, Penerbit : Prenhallindo, Jakarta.

Kotler, Philip dan Kevin Keller. 2009. Manajemen Pemasaran. Jilid 1. Edisi ke 13. Diterjemahkan oleh Bob Sabran. Jakarta: Erlangga.

Mowen, John C; Michael Minor. 2002. Perilaku Pelanggan. Edisi 5. Jakarta : Penerbit Erlangga.

Nasution, M. N. (2005). Manajemen Mutu Terpadu: Total Quality Management, Edisi Kedua, Ghalia Indonesia, Bogor.Nugroho, F.Y. 2011. Pengaruh Citra Merek dan Kepuasan Pelanggan Terhadap Loyalitas Pelanggan. Jurnal. Fakultas Pertanian Universitas Pembangunan Nasional "Veteran". Yogyakarta.

Peter, J. Paul dan Jerry C. Olson. 2000. Consumer Behavior. Perilaku pelanggan dan Strategi Pemasaran. Jilid 2. Edisi 4. Diterjemahkan oleh: Damos Sihombing. Jakarta: Erlangga.

Rangkuti, Freddy. 2002. Measuring customer satisfaction. Jakarta: Gramedia Pustaka

Setiadi, N. J. 2003. Perilaku Pelanggan : Konsep dan Implikasi untuk Strategi dan Penelitian Pemasaran. Jakarta: Prenada Media

Soim et al. 2016. Pengaruh Brand Image Terhadap Keputusan Pembelian (Studi pada Pembeli Kartu Perdana simPATI di Booth Telkomsel Matos). Jurnal Administrasi Bisnis.Vol. 35 No. 1

Supriyadi et al (2016). Pengaruh Kualitas Produk Dan Brand Image Terhadap Keputusan Pembelian. Jurnal Bisnis dan Manajemen.Vol. 3 No.1

Thakur, Satendra. 2012. "Brand Image, Customer Satisfaction and Loyalty Intention". International Journal of Multidisciplinary Management Studies, Vol. 2(5), ISSN 22498834.

Tjiptono, Fandy. 2005. Strategi Pemasaran. Edisi kedua. Yogyakarta: Andi. 
Pengaruh Brand Image dan Kualitas Produk Terhadap Keputusan Pembelian pada KFC di Kota Bengkulu. 